\title{
COAL CONVERSION WASTEWATER TREATMENT BY CATALYTIC OXIDATION IN SUPERCRITICAL WATER
}

Final Technical Report

Grant Number: DE-FG22-95PC95213

Awarded to: The University of Michigan

Report Date: October 18, 1999

Grant Date: June 30, 1995

Completion Date: June 30, 1999

Government Award: $\$ 200,000$ over 4 years

Principal Investigator: Phillip E. Savage

Contracting Officer's Representative: Kamalendu Das

Reporting Period: July 1, 1995 - June 30, 1999 


\section{Disclaimer}

This report was prepared as an account of work sponsored by an agency of the United States Government. Neither the United States Government nor any agency thereof, nor any of their employees, makes any warranty, express or implied, or assumes any legal liability or responsibility for the accuracy, completeness, or usefulness of any information, apparatus, product, or process disclosed, or represents that its use would not infringe privately owned rights. Reference herein to any specific commercial product, process, or service by trademark, manufacturer, or otherwise does not necessarily constitute or imply its endorsement, recommendation, or favoring by the United States Government or any agency thereof. The views and opinions of authors expressed herein do not necessarily state or reflect those of the United States Government or any agency thereof. 
Final Technical Report

\begin{abstract}
Wastewaters from coal-conversion processes contain phenolic compounds in appreciable concentrations. These compounds need to be removed so that the water can be discharged or re-used. Catalytic oxidation in supercritical water is one potential means of treating coal-conversion wastewaters, and this project examined the reactions of phenol over different heterogeneous oxidation catalysts in supercritical water. More specifically, we examined the oxidation of phenol over a commercial catalyst and over bulk $\mathrm{MnO}_{2}$, bulk $\mathrm{TiO}_{2}$, and $\mathrm{CuO}$ supported on $\mathrm{Al}_{2} \mathrm{O}_{3}$. We used phenol as the model pollutant because it is ubiquitous in coal-conversion wastewaters and there is a large database for non-catalytic supercritical water oxidation (SCWO) with which we can contrast results from catalytic SCWO. The overall objective of this research project is to obtain the reaction engineering information required to evaluate the utility of catalytic supercritical water oxidation for treating wastes arising from coal conversion processes.
\end{abstract}

All four materials were active for catalytic supercritical water oxidation. Indeed, all four materials produced phenol conversions and $\mathrm{CO}_{2}$ yields in excess of those obtained from purely homogeneous, uncatalyzed oxidation reactions. The commercial catalyst was so active that we could not reliably measure reaction rates that were not limited by pore diffusion. Therefore, we performed experiments with bulk transition metal oxides.

The bulk $\mathrm{MnO}_{2}$ and $\mathrm{TiO}_{2}$ catalysts enhance both the phenol disappearance and $\mathrm{CO}_{2}$ formation rates during SCWO. $\mathrm{MnO}_{2}$ does not affect the selectivity to $\mathrm{CO}_{2}$, or to the phenol dimers at a given phenol conversion. However, the selectivities to $\mathrm{CO}_{2}$ are increased and the selectivities to phenol dimers are decreased in the presence of $\mathrm{TiO}_{2}$, which are desirable trends for a catalytic SCWO process. The role of the catalyst appears to be accelerating the rate of formation of phenoxy radicals, which then react in the fluid phase by the same mechanism operative for non-catalytic SCWO of phenol. The rates of phenol disappearance and $\mathrm{CO}_{2}$ formation are sensitive to the phenol and $\mathrm{O}_{2}$ concentrations, but independent of the water density. Power-law rate expressions were developed to correlate the catalytic kinetics. The catalytic kinetics were also consistent with a Langmuir-Hinshelwood rate law derived from a dual-site mechanism comprising the following steps: reversible adsorption of phenol on one type of catalytic site, reversible dissociative adsorption of oxygen on a different type of site, and irreversible, rate-determining surface reaction between adsorbed phenol and adsorbed oxygen. 


\section{TABLE OF CONTENTS}

1. Executive Summary

2. Introduction

6

3. Experimental Section

4. Results and Discussion

8

4.1 Commercial VOC Oxidation Catalyst

8

4.2 $\quad \mathrm{MnO}_{2}$ Catalyst

11

4.3 CuO Catalyst

18

4.4 $\mathrm{TiO}_{2}$ Catalyst

20

5. Conclusions

6. References

25 


\section{EXECUTIVE SUMMARY}

Phenol, a compound representative of those most commonly found in coal conversion wastewaters, was oxidized in supercritical water over four different heterogeneous catalysts. The objective of this experimental research project was to obtain the reaction engineering information required to evaluate the utility of catalytic supercritical water oxidation (SCWO) for treating wastes arising from coal conversion processes.

Carulite 150, a commercial VOC (volatile organic compound) oxidation catalyst, was both active and selective for phenol SCWO. In fact, this commercial catalyst was so active that pore diffusion always limited the observed reaction rate, and we were not able to measure the intrinsic kinetics. Bulk $\mathrm{MnO}_{2}$ and $\mathrm{TiO}_{2}$ were also active for phenol SCWO, and $\mathrm{TiO}_{2}$ altered the selectivity to $\mathrm{CO}_{2}$. The role of the catalyst appears to be accelerating the rate of formation of phenoxy radicals, which then react in the fluid phase by the same mechanism operative for non-catalytic SCWO of phenol. The rates of phenol disappearance and $\mathrm{CO}_{2}$ formation are sensitive to the phenol and $\mathrm{O}_{2}$ concentrations, but independent of the water density. Both powerlaw and dual site Langmuir-Hinshelwood-Hougen-Watson (LHHW) rate laws were developed to correlate the catalytic kinetics. These rate laws can be used for SCWO reactor sizing and subsequent economic analysis for catalytic SCWO of coalconversion wastewaters. 


\section{INTRODUCTION}

Supercritical water oxidation (SCWO) is a waste-treatment process that converts organic carbon to $\mathrm{CO}_{2}$ at reaction conditions that exceed the critical point of water ( Tc $=374{ }^{\circ} \mathrm{C}, \mathrm{Pc}=218 \mathrm{~atm}$.). Water above its critical point is a good solvent for both oxygen and organic compounds, which allows these components to react quickly in a homogeneous fluid phase (Modell, 1989).

Information about the kinetics and byproducts from oxidation of real aqueous pollutants is essential for the design of reliable commercial SCWO reactors. A knowledge of the reaction kinetics allows one to calculate the catalyst amounts or reactor volumes required for a desired destruction and removal efficiency in a commercial SCWO reactor. A knowledge of the identities and yields of reaction products allows one to identify processing conditions that minimize the production of undesired intermediate byproducts.

Savage and coworkers $(1995,1999)$ review previous SCWO research with model pollutants, and these reviews showed that phenolic compounds are the model pollutants studied most extensively at SCWO conditions. This attention is a reflection of phenol and substituted phenols having high water solubilities, which cause them to appear in industrial wastewaters including those from coalconversion processes (e.g., Yen et al., 1982; Jevtitch and Bhattacharyya, 1986). Even though phenolic compounds have received some attention for conventional homogeneous SCWO treatment, there has been much less research into the catalytic SCWO of phenol.

There has been increasing interest in the use of heterogeneous catalysts in SCWO. Catalysts can increase the oxidation rates, reduce the residence times and temperatures required for treatment, and possibly provide control over competing reaction pathways that is difficult to achieve in non-catalytic processes. A review article (Ding et al., 1996) fully describes the potential advantages of catalytic SCWO for destroying organic wastes. Additionally, Aki and Abraham (1998) recently reported that catalytic SCWO could be more economical than incineration and other hydrothermal oxidation technologies.

The prior work on catalytic SCWO of phenol focused mostly on treatability studies rather than more fundamental reaction engineering investigations. The first catalytic oxidation of phenol in supercritical water used $\mathrm{CuO}$ and $\mathrm{ZnO}$ supported by a porous cement (Krajnc and Levec, 1994). High conversions were obtained in the presence of the catalyst. Using the same catalyst, Krajnc and Levec (1997) did more experiments that led to a Langmuir-Hinshelwood rate law for catalytic SCWO of phenol. They classified the products into four groups: dimers, single-ring compounds, organic acids, and gases. Ding et al., (1995) demonstrated that the conversion of phenol to $\mathrm{CO}_{2}$ could be increased by using $\mathrm{MnO}_{2} / \mathrm{CeO}_{2}$ or $\mathrm{V}_{2} \mathrm{O}_{5}$ catalysts. They also noted that $\mathrm{MnO}_{2} / \mathrm{CeO}_{2}$ is the most effective and the most stable catalyst among $\mathrm{V}_{2} \mathrm{O}_{5}, \mathrm{MnO}_{2} / \mathrm{CeO}_{2}$ and $\mathrm{Cr}_{2} \mathrm{O}_{3} / \mathrm{Al}_{2} \mathrm{O}_{3}$. The limited information 
Final Technical Report

available on the reaction kinetics and pathways for catalytic oxidation of phenol in supercritical water and the importance of phenolic compounds in coal-conversion wastewaters motivated this study of the catalytic reactions of phenol in supercritical water.

\section{EXPERIMENTAL SECTION}

All experiments were performed in a tubular flow reactor that can be approximated as operating isothermally, isobarically and in plug-flow. The details of the flow reactor system have been published (Zhang and Savage, 1998). A dilute aqueous solution of $\mathrm{H}_{2} \mathrm{O}_{2}$ is loaded into a pressure vessel and then blanketed with 600 psi of helium. An aqueous solution of phenol is loaded into a separate pressure vessel and likewise blanketed with 600 psi of helium. The aqueous solutions in the feed tanks form two feed streams, which are pressurized and pumped through separate preheat lines and then the reactor using two Eldex model AA-100-S micrometer pumps. During the preheating, $\mathrm{H}_{2} \mathrm{O}_{2}$ completely decomposed into $\mathrm{O}_{2}$ and water. That decomposition was complete was verified experimentally. The two streams are preheated separately in two 1/16-in. (1.6-mm) O.D. feed lines before being mixed in a Hastelloy C-276 cross which was fitted with a thermocouple. The reaction temperatures reported in this study are those detected by this thermocouple. The mixed feed streams then entered the reactor, which is assembled from 1/4-in stainless steel Swagelok tube fittings (a union and two port connectors). A Hastelloy porous disk with up to $100 \mathrm{~mm}$ openings was placed at each end to keep the catalyst inside the union. The entire reactor assembly (including preheater line, mixing cross and reactor) was housed in a temperature-controlled Techne model SBL-2 fluidized sand bath that maintains isothermality to within $1^{\circ} \mathrm{C}$.

Upon leaving the heated zone of the sand bath, the reactor effluent was cooled in two consecutive tube-in-tube heat exchangers and then depressurized in a Tescom model 44 back pressure regulator. The exiting stream was separated into gas and liquid phases (at ambient conditions) in a liquid trap. These two phases were assumed to be in equilibrium, and Henry's law was used to calculate the amount of $\mathrm{CO}$ and $\mathrm{CO}_{2}$ dissolved in the liquid phase. The gas flow rate was measured with a bubble meter at the outlet of the system, and the gas stream was sent to an on-line gas chromatograph (GC) equipped with a thermal conductivity detector for analysis. The liquid flow rate was determined by measuring the volume collected in a graduated cylinder within a fixed time period, and samples of the liquid phase were retained for analysis.

The gaseous reactor effluent was analyzed by a Hewlett Packard model 5890 GC with a Supelco 10-ft. by 1/8-in. O.D. stainless steel column packed with 100/120 mesh Carbosieve S-II. A 10-port Valco valve injected a $0.5 \mathrm{ml}$ sample into the column, and helium flowing at $20 \mathrm{ml} / \mathrm{min}$ served as the carrier gas. The oven temperature program was $35^{\circ} \mathrm{C}$ for the first 7 minutes, and then a ramp of $16^{\circ} \mathrm{C} / \mathrm{min}$ up to $225^{\circ} \mathrm{C}$. Detector response factors for $\mathrm{CO}_{2}$ and $\mathrm{CO}$ were determined experimentally using standard gases. 
A reverse-phase high-performance liquid chromatograph with a Supelco C18 column was used to determine the concentration of phenol in the liquid effluent samples. Analyses were performed isocratically with a mobile phase of acetonitrile and water (30:70 by volume). The mobile phase flow rate was $1 \mathrm{ml} / \mathrm{min}$, and the UV absorbance at a wavelength of $210 \mathrm{~nm}$ was monitored.

Higher molecular weight products of incomplete oxidation, which are present in much lower concentrations than phenol, were extracted from the aqueous effluent with dichloromethane. After concentrating the dichloromethane solution, the products were qualitatively analyzed by capillary column gas chromatography with a mass spectrometric detector (GC-MS). Details of the procedures have been published (Thornton et al., 1991).

The CARULITE 150 catalyst used was obtained from Carus Chemical Company. The active ingredients are $45-60 \% \mathrm{MnO}_{2}$ and $1-3 \% \mathrm{CuO}$, which are supported on amorphous $\mathrm{Al}_{2} \mathrm{O}_{3}$. The other catalysts $\left(\mathrm{MnO}_{2}, \mathrm{TiO}_{2}\right.$, and $\left.\mathrm{CuO} / \mathrm{Al}_{2} \mathrm{O}_{3}\right)$ were purchased from Aldrich and used as received. The catalyst pellets obtained were ground to powders and separated by size. Particles within the size range of 0.12 to $0.25 \mathrm{~mm}$ (or 60/120 mesh) were used in order to ensure that they would not go through the porous disk with $100 \mu \mathrm{m}$ opening. The catalyst was pretreated overnight by flowing a supercritical water stream carrying just oxygen through the reactor. Yu and Savage (1999) provide additional details.

\section{RESULTS AND DISCUSSION}

This section provide the experimental results for the four different catalysts and then discusses their significance.

\subsection{Commercial VOC Oxidation Catalyst}

Our investigation of a commercial VOC oxidation catalyst for catalytic SCWO has been published (Zhang and Savage, 1998). In this section we summarize the highlights from this study.

Table 1 summarizes all the experimental conditions and results for the commercial VOC oxidation catalyst. The gaseous product yields were calculated as the molar flow rate of $\mathrm{CO}_{2}$ (or $\mathrm{CO}$ ) in the reactor effluent divided by 6 times the molar flow rate of phenol into the reactor. The phenol conversions are always greater than $70 \%$. In addition, the selectivity to complete oxidation, which is calculated as the ratio of the yield of $\mathrm{CO}_{2}$ to the phenol conversion, ranges from $52 \%$ to essentially $100 \%$. It is generally higher than that obtained from the non-catalytic SCWO of phenol at comparable temperatures.

Due to this higher selectivity to $\mathrm{CO}_{2}$ formation there must be a smaller amount of byproducts formed than from non-catalytic SCWO. This expectation was confirmed by a GC-MS analysis of the liquid effluent from one of the runs. This analysis 
revealed the presence of 2,5-cyclohexadiene-1,4-dione and trace amounts of 2- or 4phenoxyphenol as products of incomplete oxidation. Dibenzo-p-dioxin, dibenzofuran, 2-dibenzofuranol, etc., which are produced as intermediate products from the non-catalytic SCWO of phenol (Thornton et al., 1991; Thornton and Savage, 1992a), were not detected here. This difference suggests that catalytic SCWO with this commercial catalyst involves new and faster pathways so that the non-catalytic dimerization pathway is suppressed.

We calculated the phenol conversion and $\mathrm{CO}_{2}$ yield that would be produced by noncatalytic SCWO under the present experimental conditions on the basis of the rate laws previously established (Thornton and Savage, 1992b; Gopalan and Savage, 1995). These calculations show that the non-catalytic contributions to the phenol conversion and the $\mathrm{CO}_{2}$ yield are only a small portion of the experimentally observed values. The fraction of the $\mathrm{CO}_{2}$ yield produced experimentally that can be attributed to non-catalytic oxidation reactions is always smaller than $6 \%$.

Table 1. Summary of phenol oxidation experiments over CARULITE 150 at $250 \mathrm{~atm}$

\begin{tabular}{|c|c|c|c|c|c|c|c|c|c|c|}
\hline \multirow[b]{2}{*}{$\begin{array}{l}\text { Temp. } \\
\left({ }^{\circ} \mathrm{C}\right)\end{array}$} & \multirow{2}{*}{$\begin{array}{c}\text { Space } \\
\text { Time } \\
\text { (s) }\end{array}$} & \multirow{2}{*}{$\begin{array}{c}\text { Phenol } \\
\text { Conc. } \\
(\mathrm{mmol} / \mathrm{L})\end{array}$} & \multirow{2}{*}{$\begin{array}{c}\text { Oxygen } \\
\text { Conc. } \\
(\mathrm{mmol} / \mathrm{L})\end{array}$} & \multirow{2}{*}{$\begin{array}{l}\text { Phenol } \\
\text { Conv. } \\
(\%)\end{array}$} & \multirow{2}{*}{$\begin{array}{c}\mathrm{CO} 2 \\
\text { Yield } \\
(\%)\end{array}$} & \multirow{2}{*}{$\begin{array}{c}\mathrm{CO} \\
\text { Yield } \\
(\%)\end{array}$} & \multicolumn{2}{|c|}{ Phenol Conv. } & \multicolumn{2}{|c|}{ CO2 form. } \\
\hline & & & & & & & $\begin{array}{c}\mathrm{k} 1 \\
(\mathrm{~L} / \mathrm{g} \mathrm{s})\end{array}$ & $\eta$ & $\begin{array}{c}\mathrm{k} 1 \\
(\mathrm{~L} / \mathrm{g} \mathrm{s})\end{array}$ & $\eta$ \\
\hline 385 & 0.51 & 0.720 & 34.1 & 97 & 80 & 0.1 & 0.042 & 0.47 & 0.013 & 0.68 \\
\hline 384 & 0.35 & 1.029 & 24.8 & 88 & 76 & 0.4 & 0.032 & 0.51 & 0.017 & 0.62 \\
\hline 384 & 0.25 & 1.237 & 18.1 & 83 & 43 & 0.4 & 0.042 & 0.45 & 0.008 & 0.76 \\
\hline 384 & 0.25 & 0.831 & 38.0 & 85 & 66 & 0.4 & 0.043 & 0.44 & 0.018 & 0.60 \\
\hline 383 & 0.19 & 1.078 & 29.8 & 74 & 57 & 0.5 & 0.037 & 0.46 & 0.018 & 0.59 \\
\hline 382 & 0.17 & 0.908 & 39.6 & 75 & 47 & 0.3 & 0.046 & 0.42 & 0.014 & 0.63 \\
\hline 385 & 0.41 & 0.762 & 35.8 & 92 & 80 & 0.3 & 0.033 & 0.50 & 0.017 & 0.63 \\
\hline 384 & 0.26 & 1.118 & 23.2 & 80 & 64 & 0.4 & 0.032 & 0.50 & 0.016 & 0.63 \\
\hline 387 & 0.79 & 0.452 & 36.4 & 100 & 81 & 0.0 & & & 0.009 & 0.77 \\
\hline 387 & 0.58 & 0.683 & 27.1 & 100 & 78 & 0.0 & & & 0.012 & 0.73 \\
\hline 388 & 1.81 & 0.298 & 38.6 & 100 & 100 & 0.0 & & & & \\
\hline 388 & 1.24 & 0.575 & 26.4 & 100 & 95 & 0.0 & & & 0.012 & 0.75 \\
\hline 387 & 0.78 & 0.890 & 18.2 & 99 & 85 & 0.2 & 0.077 & 0.39 & 0.011 & 0.74 \\
\hline 387 & 1.06 & 0.365 & 39.1 & 100 & 100 & 0.0 & & & & \\
\hline 387 & 0.76 & 0.624 & 28.9 & 97 & 78 & 0.7 & 0.039 & 0.50 & 0.008 & 0.79 \\
\hline 386 & 0.61 & 0.784 & 23.6 & 95 & 71 & 0.7 & 0.027 & 0.58 & 0.008 & 0.78 \\
\hline 387 & 0.58 & 1.055 & 9.60 & 94 & 51 & 0.4 & 0.027 & 0.57 & 0.005 & 0.86 \\
\hline 426 & 0.40 & 0.086 & 17.6 & 98 & 100 & 2.6 & 0.030 & 0.56 & & \\
\hline 417 & 0.26 & 0.164 & 12.3 & 82 & 69 & 2.2 & 0.093 & 0.50 & 0.053 & 0.60 \\
\hline 401 & 0.20 & 0.243 & 11.1 & 63 & 49 & 1.4 & 0.054 & 0.56 & 0.031 & 0.66 \\
\hline 430 & 0.32 & 0.070 & 18.2 & 95 & 89 & 3.1 & 0.199 & 0.39 & 0.114 & 0.48 \\
\hline 425 & 0.23 & 0.133 & 13.3 & 84 & 70 & 2.5 & 0.141 & 0.44 & 0.075 & 0.55 \\
\hline 427 & 0.20 & 0.070 & 18.8 & 82 & 82 & 3.3 & 0.162 & 0.41 & 0.161 & 0.41 \\
\hline
\end{tabular}


The experimental data in Table 1 clearly show that complete oxidation of phenol to $\mathrm{CO}_{2}$ is achievable in about 2 second of space time (defined here as the ratio of the catalyst mass to the fluid mass flow rate), which is equivalent to about 1 second of contact time (defined here as the ratio of catalyst bulk volume to fluid volumetric flow rate). That the heterogeneous catalyst effectively increases the reaction rate and promotes complete oxidation to $\mathrm{CO}_{2}$ is in agreement with previous reports on heterogeneous catalytic SCWO of phenol. While the previous studies (Ding et al., 1995, 1996; Krajnc and Levec, 1994) reported that the yield of $\mathrm{CO}_{2}$ reached as high as $90 \%$ in 5.4 seconds of contact time and $100 \%$ in 15 seconds at relatively mild temperatures of $\sim 390{ }^{\circ} \mathrm{C}$, the results here show that complete oxidation of phenol can be achieved in an even shorter time period using the CARULITE 150 catalyst.

\section{M ass Transport Influence}

Before using the experimental data to determine the catalytic oxidation kinetics, we first assessed the influence of mass transfer on the observed reaction rate. Mass transfer from the bulk fluid to the catalyst surface (external mass transfer) can limit an observed catalytic reaction rate, as can mass transfer within the pores of the catalyst particle (internal mass transfer). We first used the Mears' criterion (Fogler, 1998) to determine whether external mass transfer limited the rate of oxidation of phenol under the reaction conditions employed in our experiments. Our analysis led us to conclude that external mass transfer did not influence the overall kinetics during our experiments. We next used the Weisz-Prater criterion to test for possible pore diffusion limitations. This analysis revealed that pore diffusion was in fact inhibiting the reaction rate. Thus, the rates we observed experimentally were not the intrinsic reaction rates, but rather the diffusion-limited rates.

\section{Kinetics A nalysis}

In light of the internal mass transfer limitation on the kinetics, it was evident that the influence of pore diffusion must be accounted for in any kinetics analysis. We chose to include pore diffusion effects by using the effectiveness factor $(\eta)$ in our kinetics analysis. The first stage in our analysis was to determine the reaction order. We performed a non-linear regression analysis to fit the phenol conversions from experiments conducted around $385^{\circ} \mathrm{C}$ to a power-law kinetics model. These data sets led to global reaction orders of 0.94 for phenol, and 0.29 for oxygen. Similarly, a consideration of the kinetics for the formation of $\mathrm{CO}_{2}$, which is equivalent to the rate of disappearance of total organic carbon (TOC), leads to apparent reaction orders for $\mathrm{CO}_{2}$ formation of 1.17 for TOC and 0.25 for oxygen.

The apparent reaction orders for phenol in the phenol disappearance rate equation and for TOC in the $\mathrm{CO}_{2}$ formation rate law are close to unity, which implies that the true reaction orders are close to unity in both cases. Meanwhile, the effect of oxygen on the reaction rate is much smaller, so we approximated the intrinsic kinetics for both phenol and TOC conversion as following a rate law that is first order in the organic compound and zero order in oxygen. 
An analytical solution exists for the reaction-diffusion problem involving an isothermal first-order reaction. Using this analytical expression for the effectiveness factor, we were able to calculate the rate constant $\left(\mathrm{k}_{1}\right)$ for each experimental run. Table 1 displays the results of this analysis. The effectiveness factors range from 0.38 to 0.58 , which confirms the mass transfer limitation on the intrinsic kinetics of phenol conversion during our experiments. The activation energy and preexponential factor for phenol disappearance were determined as $E_{a}=30.7 \mathrm{kcal} / \mathrm{mol}$, and $\mathrm{A}=108.8 \mathrm{~L} / \mathrm{g} \mathrm{s}$. We also used the approach outlined above to evaluate the intrinsic kinetics for the TOC conversion, and the first-order rate constants we obtained appear in Table 1. The Arrhenius parameters are $\mathrm{E}_{\mathrm{a}}=46.9 \mathrm{kcal} / \mathrm{mol}, \mathrm{A}=$ $1014 \mathrm{~L} / \mathrm{g}$ s.

\section{2 $\mathrm{MnO}_{2}$ Catalyst}

As noted in the previous section, the catalytic SCWO of phenol over the $\mathrm{CuO}+\mathrm{MnO}_{2} / \mathrm{Al}_{2} \mathrm{O}_{3}$ commercial catalyst (CARULITE 150) resulted in a conversion of phenol to $\mathrm{CO}_{2}$ much higher than that produced by non-catalytic oxidation. The commercial catalyst was so active that the rate of pore diffusion limited the oxidation rate and made kinetics analysis difficult. Nevertheless, we were able to develop a simple first-order rate law that adequately described the experimental data. One of the pressing needs (Matatov-Meytal and Sheintuch, 1998) in this field, however, is the development of reliable rate laws for catalytic SCWO that could be used for engineering purposes. Therefore, we initiated experiments with bulk $\mathrm{MnO}_{2}$, which is a component in but much less active than the optimized commercial catalyst.

Our investigation of catalytic SCWO using bulk $\mathrm{MnO}_{2}$ has very recently been published ( $\mathrm{Yu}$ and Savage, 1999). We provide an overview of this work in this section. We conducted numerous experiments with bulk $\mathrm{MnO}_{2}$ to explore the relevant parameter space (temperature, pressure, and concentrations). Table 2 provides the experimental results. $\mathrm{W} / \mathrm{F}$ Ao is the ratio of catalyst mass in the reactor to the phenol molar flow rate at the reactor entrance.

Conversion of organic compounds to $\mathrm{CO}_{2}$ is the main objective of a wastewater treatment technology. Thus, how much $\mathrm{CO}_{2}$ can be obtained is one of the important factors to evaluate the catalyst effectiveness. Fig. 1 and Fig. 2 compare the phenol conversion and molar yield of $\mathrm{CO}_{2}$ without catalyst (Gopalan and Savage, 1995; Li et al., 1992) and with $\mathrm{MnO}_{2}$ catalyst in supercritical water at $380^{\circ} \mathrm{C}$ and $250 \mathrm{~atm}$. Clearly, both the phenol conversion and the $\mathrm{CO}_{2}$ molar yield with catalyst are much higher than those without catalyst for phenol oxidation in supercritical water. At the identical experimental conditions, the molar yields of $\mathrm{CO}_{2}$ are typically close to zero during non-catalytic SCWO of phenol, but are increased to over $40 \%$ during catalytic SCWO of phenol. Likewise, the phenol conversion is less than $30 \%$ without catalyst, but nearly $90 \%$ with catalyst. These results confirm that the presence of the 
Final Technical Report

$\mathrm{MnO}_{2}$ catalyst can enhance both phenol conversion and $\mathrm{CO}_{2}$ molar selectivity during SCWO. 


\section{Table 2. Summary of Phenol oxidation over $\mathrm{MnO}_{2}$ in SCW}

\begin{tabular}{|c|c|c|c|c|c|c|c|c|c|}
\hline $\begin{array}{c}\text { Reaction } \\
\text { Pressure } \\
\text { (atm) }\end{array}$ & $\begin{array}{l}\text { Reaction } \\
\text { Temp. } \\
\quad\left({ }^{\circ} \mathrm{C}\right)\end{array}$ & $\begin{array}{c}\text { (kgcat.s } / \mathrm{m} \\
\mathrm{mol})\end{array}$ & $\begin{array}{c}\mathrm{PhOH} \\
\text { Conc. } \\
\text { (mmol/L) }\end{array}$ & $\begin{array}{c}\text { Water } \\
\text { Conc. } \\
\text { (mol/L) }\end{array}$ & $\begin{array}{l}\text { Oxygen } \\
\text { Conc. } \\
\text { (mmol/L) }\end{array}$ & $\begin{array}{c}\mathrm{PhOH} \\
\text { Conv. } \\
(\%)\end{array}$ & $\begin{array}{l}\mathrm{CO} \\
\text { Yield } \\
(\%)\end{array}$ & $\begin{array}{c}\mathrm{CO}_{2} \\
\text { Yield } \\
(\%)\end{array}$ & $\begin{array}{c}\text { Carbon } \\
\text { Tally } \\
(\%)\end{array}$ \\
\hline 250 & 381 & 8.26 & 0.68 & 24.9 & 25.5 & 87 & 3.1 & 38 & 55 \\
\hline 250 & 380 & 5.47 & 0.70 & 25.3 & 25.3 & 69 & 2.3 & 25 & 58 \\
\hline 250 & 381 & 4.32 & 0.68 & 25.0 & 25.5 & 60 & 1.6 & 19 & 60 \\
\hline 250 & 381 & 3.51 & 0.68 & 25.1 & 25.7 & 50 & 1.4 & 14 & 65 \\
\hline 250 & 381 & 4.20 & 1.08 & 24.9 & 30.3 & 71 & 2.1 & 26 & 57 \\
\hline 250 & 381 & 3.98 & 1.38 & 25.2 & 24.8 & 70 & 2.4 & 25 & 57 \\
\hline 250 & 381 & 2.81 & 1.35 & 25.1 & 25.1 & 58 & 1.2 & 12 & 55 \\
\hline 250 & 381 & 2.14 & 1.37 & 25.2 & 24.9 & 46 & 0.9 & 9 & 64 \\
\hline 250 & 380 & 1.68 & 1.39 & 25.5 & 25.2 & 36 & 0.8 & 6 & 71 \\
\hline 250 & 381 & 2.02 & 2.72 & 25.1 & 24.8 & 62 & 1.2 & 13 & 52 \\
\hline 250 & 381 & 2.11 & 2.18 & 25.2 & 30.6 & 58 & 1.6 & 13 & 57 \\
\hline 250 & 381 & 1.49 & 2.58 & 24.9 & 25.9 & 43 & 0.9 & 7 & 65 \\
\hline 250 & 381 & 1.10 & 2.69 & 25.1 & 25.2 & 45 & 0.5 & 4 & 60 \\
\hline 250 & 381 & 0.93 & 2.62 & 25.2 & 26.0 & 45 & 0.7 & 3 & 60 \\
\hline 250 & 381 & 5.74 & 1.32 & 25.1 & 21.9 & 84 & 0.1 & 6 & 22 \\
\hline 250 & 381 & 2.77 & 1.62 & 25.0 & 19.1 & 60 & 0.8 & 11 & 51 \\
\hline 250 & 381 & 3.78 & 1.32 & 24.5 & 21.1 & 72 & 1.2 & 13 & 43 \\
\hline 250 & 381 & 2.96 & 1.33 & 24.9 & 21.5 & 53 & 0.9 & 8 & 56 \\
\hline 250 & 381 & 1.15 & 2.03 & 25.2 & 15.8 & 39 & 0.1 & 2 & 63 \\
\hline 250 & 380 & 6.29 & 1.29 & 25.4 & 34.9 & 82 & 1.6 & 22 & 41 \\
\hline 250 & 381 & 2.73 & 1.60 & 24.9 & 29.7 & 57 & 0.9 & 10 & 54 \\
\hline 250 & 381 & 1.91 & 2.00 & 25.2 & 24.8 & 49 & 0.5 & 7 & 58 \\
\hline 250 & 381 & 1.44 & 1.99 & 25.1 & 24.8 & 35 & 0.4 & 4 & 70 \\
\hline 250 & 381 & 1.12 & 2.03 & 25.1 & 24.2 & 32 & 0.3 & 3 & 71 \\
\hline 250 & 381 & 5.38 & 1.32 & 24.4 & 51.4 & 87 & 2.4 & 44 & 60 \\
\hline 250 & 382 & 2.91 & 1.54 & 24.2 & 46.2 & 72 & 1.4 & 25 & 55 \\
\hline 250 & 382 & 1.94 & 1.90 & 24.1 & 38.2 & 69 & 1.2 & 20 & 52 \\
\hline 250 & 381 & 1.46 & 1.95 & 24.4 & 37.9 & 62 & 0.8 & 13 & 52 \\
\hline 250 & 381 & 1.14 & 1.97 & 24.7 & 38.3 & 49 & 0.4 & 11 & 62 \\
\hline 250 & 382 & 2.83 & 1.85 & 24.0 & 30.0 & 76 & 1.6 & 30 & 56 \\
\hline 250 & 382 & 1.91 & 1.90 & 24.1 & 29.5 & 65 & 1.0 & 19 & 55 \\
\hline 250 & 382 & 1.46 & 1.91 & 24.2 & 29.8 & 52 & 0.6 & 12 & 60 \\
\hline 250 & 382 & 1.36 & 1.90 & 24.2 & 29.9 & 43 & 0.4 & 10 & 67 \\
\hline 250 & 382 & 1.15 & 1.95 & 24.3 & 29.4 & 44 & 0.3 & 8 & 64 \\
\hline 250 & 385 & 9.64 & 0.30 & 20.6 & 16.5 & 70 & 1.1 & 24 & 55 \\
\hline 250 & 385 & 16.97 & 0.18 & 20.6 & 24.3 & 69 & 2.0 & 32 & 66 \\
\hline 250 & 385 & 11.50 & 0.23 & 20.4 & 20.9 & 57 & 1.2 & 20 & 64 \\
\hline 250 & 385 & 8.66 & 0.27 & 20.6 & 18.6 & 49 & 1.2 & 14 & 66 \\
\hline 250 & 391 & 4.30 & 0.60 & 12.6 & 24.0 & 60 & 1.7 & 9 & 51 \\
\hline 250 & 390 & 2.93 & 0.78 & 12.7 & 21.2 & 39 & 0.5 & 4 & 65 \\
\hline 250 & 391 & 2.00 & 0.96 & 12.7 & 17.8 & 26 & 0.3 & 3 & 77 \\
\hline 250 & 391 & 6.20 & 0.38 & 12.5 & 27.9 & 41 & 0.9 & 11 & 71 \\
\hline 250 & 391 & 3.22 & 0.62 & 12.7 & 23.9 & 27 & 0.4 & 7 & 80 \\
\hline 250 & 390 & 2.32 & 0.79 & 13.1 & 22.1 & 22 & 0.3 & 6 & 84 \\
\hline 250 & 390 & 1.79 & 0.91 & 12.9 & 19.4 & 20 & 0.2 & 7 & 87 \\
\hline
\end{tabular}


Final Technical Report

Table 2 (cont.). Summary of Phenol oxidation over $\mathrm{MnO}_{2}$ in SCW

\begin{tabular}{|c|c|c|c|c|c|c|c|c|c|}
\hline $\begin{array}{c}\text { Reaction } \\
\text { Pressure } \\
\text { (atm) }\end{array}$ & $\begin{array}{l}\text { Reaction } \\
\text { Temp. } \\
\left({ }^{\circ} \mathrm{C}\right)\end{array}$ & $\begin{array}{c}\mathrm{W} / \mathrm{F} \mathrm{A} 0 \\
\begin{array}{c}\text { (kgcat.s } / \mathrm{m} \\
\mathrm{mol})\end{array}\end{array}$ & $\begin{array}{c}\text { PhOH } \\
\text { Conc. } \\
\text { (mmol/L) }\end{array}$ & $\begin{array}{c}\text { Water } \\
\text { Conc. } \\
(\mathrm{mol} / \mathrm{L})\end{array}$ & $\begin{array}{c}\text { Oxygen } \\
\text { Conc. } \\
(\mathrm{mmol} / \mathrm{L})\end{array}$ & $\begin{array}{c}\text { PhOH } \\
\text { Conv. } \\
(\%)\end{array}$ & $\begin{array}{c}\mathrm{CO} \\
\text { Yield } \\
(\%)\end{array}$ & $\begin{array}{c}\mathrm{CO}_{2} \\
\text { Yield } \\
(\%)\end{array}$ & $\begin{array}{c}\text { Carbon } \\
\text { Tally } \\
(\%)\end{array}$ \\
\hline 250 & 421 & 14.90 & 0.09 & 7.4 & 7.4 & $\overline{44}$ & 2.2 & 19 & 77 \\
\hline 250 & 421 & 10.46 & 0.10 & 7.4 & 6.3 & 35 & 1.7 & 14 & 80 \\
\hline 250 & 421 & 15.40 & 0.07 & 7.4 & 8.4 & 40 & 2.2 & 23 & 85 \\
\hline 250 & 421 & 10.69 & 0.09 & 7.4 & 7.3 & 34 & 1.7 & 16 & 84 \\
\hline 250 & 421 & 8.06 & 0.10 & 7.4 & 6.4 & 30 & 1.1 & 13 & 84 \\
\hline 219 & 381 & 1.65 & 1.52 & 9.2 & 38.0 & 47 & 1.2 & 7 & 61 \\
\hline 219 & 381 & 0.63 & 2.05 & 9.2 & 29.5 & 28 & 0.5 & 2 & 75 \\
\hline 219 & 379 & 0.53 & 2.09 & 9.6 & 31.7 & 23 & 0.4 & 3 & 80 \\
\hline 219 & 391 & 4.73 & 0.34 & 7.6 & 14.8 & 49 & 1.0 & 15 & 67 \\
\hline 219 & 391 & 2.57 & 0.50 & 7.6 & 11.9 & 27 & 0.3 & 5 & 79 \\
\hline 219 & 391 & 1.88 & 0.59 & 7.6 & 10.2 & 19 & 0.0 & 2 & 83 \\
\hline 219 & 391 & 4.59 & 0.28 & 7.5 & 15.8 & 41 & 0.5 & 7 & 66 \\
\hline 219 & 391 & 2.69 & 0.41 & 7.5 & 13.5 & 21 & 0.0 & 3 & 82 \\
\hline 219 & 391 & 1.82 & 0.52 & 7.6 & 11.5 & 19 & 0.0 & 2 & 83 \\
\hline 219 & 391 & 1.42 & 0.59 & 7.6 & 10.2 & 14 & 0.0 & 1 & 87 \\
\hline 273 & 380 & 2.96 & 2.07 & 28.0 & 29.1 & 83 & 3.1 & 27 & 48 \\
\hline 273 & 380 & 2.14 & 2.04 & 28.0 & 29.7 & 67 & 1.8 & 15 & 50 \\
\hline 273 & 380 & 1.63 & 2.02 & 28.2 & 30.3 & 56 & 1.3 & 12 & 57 \\
\hline 273 & 380 & 1.33 & 1.99 & 28.1 & 30.6 & 46 & 0.8 & 7 & 62 \\
\hline 273 & 391 & 5.41 & 0.88 & 21.3 & 39.2 & 87 & 2.7 & 22 & 37 \\
\hline 273 & 391 & 2.64 & 1.41 & 21.4 & 30.6 & 66 & 1.1 & 8 & 44 \\
\hline 273 & 391 & 2.08 & 1.60 & 21.3 & 27.4 & 55 & 1.2 & 7 & 53 \\
\hline 273 & 390 & 8.22 & 0.49 & 21.9 & 47.2 & 61 & 2.8 & 24 & 65 \\
\hline 273 & 390 & 3.63 & 0.95 & 22.1 & 40.2 & 51 & 1.6 & 11 & 62 \\
\hline 273 & 390 & 2.34 & 1.27 & 22.0 & 34.7 & 39 & 0.9 & 7 & 69 \\
\hline 273 & 390 & 1.72 & 1.54 & 22.3 & 30.9 & 33 & 0.6 & 4 & 73 \\
\hline 300 & 381 & 3.37 & 2.40 & 29.4 & 23.0 & 93 & 4.1 & 49 & 59 \\
\hline 300 & 383 & 3.27 & 1.88 & 28.9 & 30.4 & 92 & 4.8 & 45 & 58 \\
\hline 300 & 381 & 2.31 & 1.84 & 29.6 & 32.6 & 74 & 2.9 & 23 & 52 \\
\hline 300 & 381 & 1.79 & 1.83 & 29.6 & 32.8 & 62 & 1.7 & 6 & 45 \\
\hline 300 & 381 & 1.40 & 1.90 & 29.6 & 31.6 & 51 & 1.1 & 10 & 60 \\
\hline 300 & 391 & 5.18 & 1.17 & 25.8 & 50.2 & 99 & 0.0 & 95 & 96 \\
\hline 300 & 391 & 2.65 & 1.77 & 25.7 & 39.0 & 93 & 6.6 & 49 & 63 \\
\hline 300 & 390 & 2.78 & 1.76 & 26.2 & 40.6 & 90 & 2.8 & 22 & 35 \\
\hline 300 & 391 & 1.94 & 2.11 & 26.1 & 33.9 & 82 & 2.0 & 15 & 35 \\
\hline 300 & 391 & 6.33 & 0.77 & 26.1 & 58.0 & 95 & 4.0 & 62 & 72 \\
\hline 300 & 391 & 3.17 & 1.29 & 26.0 & 48.5 & 91 & 3.2 & 31 & 43 \\
\hline 300 & 391 & 2.14 & 1.65 & 26.0 & 41.9 & 81 & 2.1 & 17 & 38 \\
\hline 300 & 391 & 1.58 & 1.95 & 26.0 & 36.6 & 72 & 1.5 & 12 & 42 \\
\hline
\end{tabular}




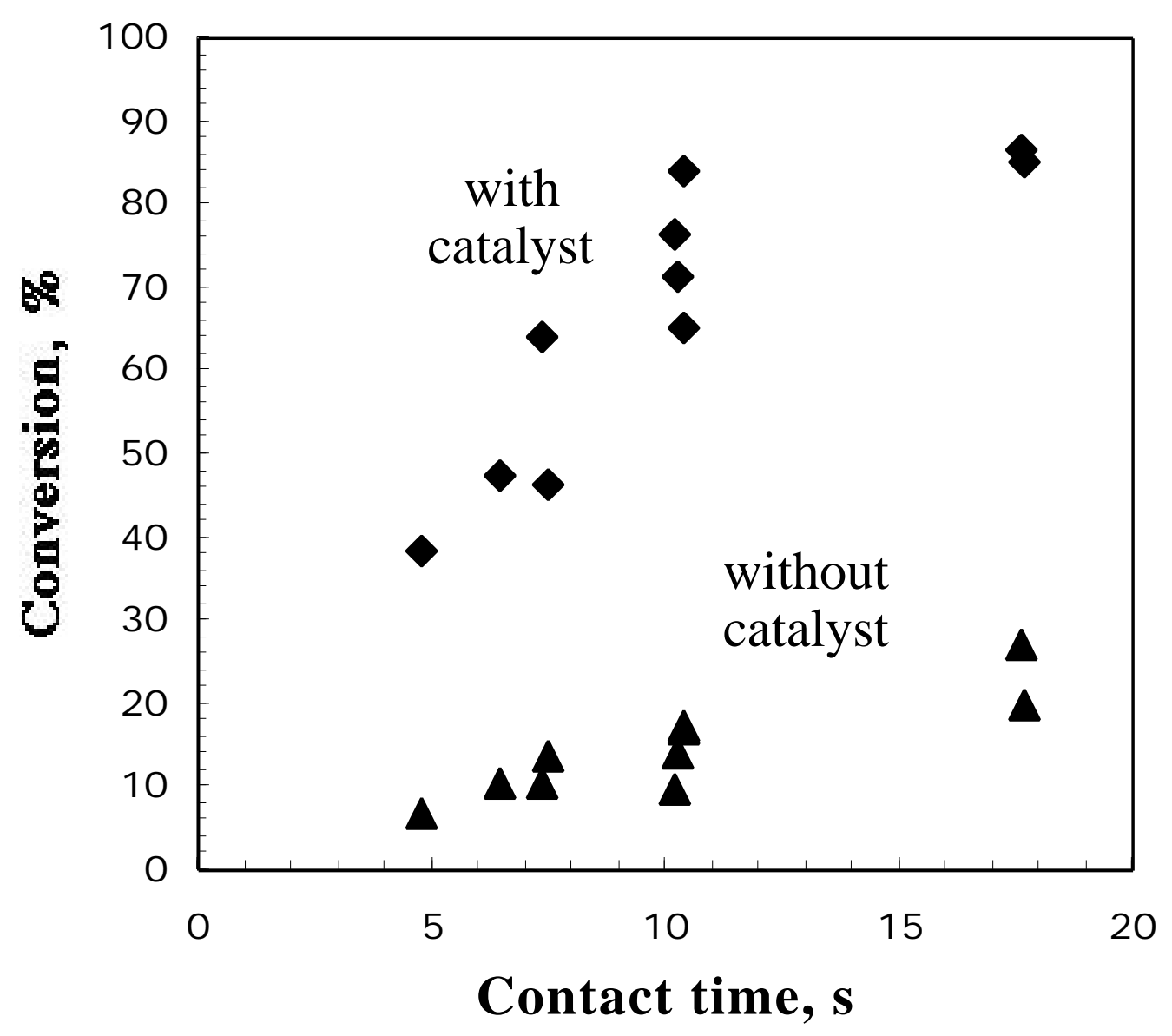

Fig. 1: Comparison of the phenol conversion with $\mathrm{MnO}_{2}$ and without $\mathrm{MnO}_{2}$

The carbon tallies being less than $100 \%$ in Table 2 imply that some intermediate products were formed during catalytic SCWO of phenol. The main intermediates in the liquid phase were 2-phenoxyphenol, 4-phenoxyphenol, xanthenone, 2,2-biphenol, 2-hydroxybenzaldehyde, dibenzofuran, dibenzo-p-dioxin, p-benzoquinone, formic acid, and acetic acid. These products were all detected in previous studies in catalytic SCWO of phenol (Krajnc and Levec, 1997) and non-catalytic SCWO of phenol (Thornton and Savage, 1992a; Thornton et al., 1991). Fig. 3 shows the relationship between the molar yields of by-products and phenol conversion at $380^{\circ} \mathrm{C}$ and $250 \mathrm{~atm}$ with $0.37 \sim 0.66 \mathrm{mmol} / \mathrm{L}$ phenol initial concentrations. The molar yields first increased with phenol conversion and then decreased. The implication is that these intermediates were formed during the phenol oxidation first, and then oxidized to carbon dioxide and water.

M ass Transport Influence

We used the Mears and Weisz-Prater criteria to test for possible mass transport intrusions on the measured reaction rates. These criteria revealed that the data obtained can be attributable to the intrinsic reaction rate. 
Final Technical Report

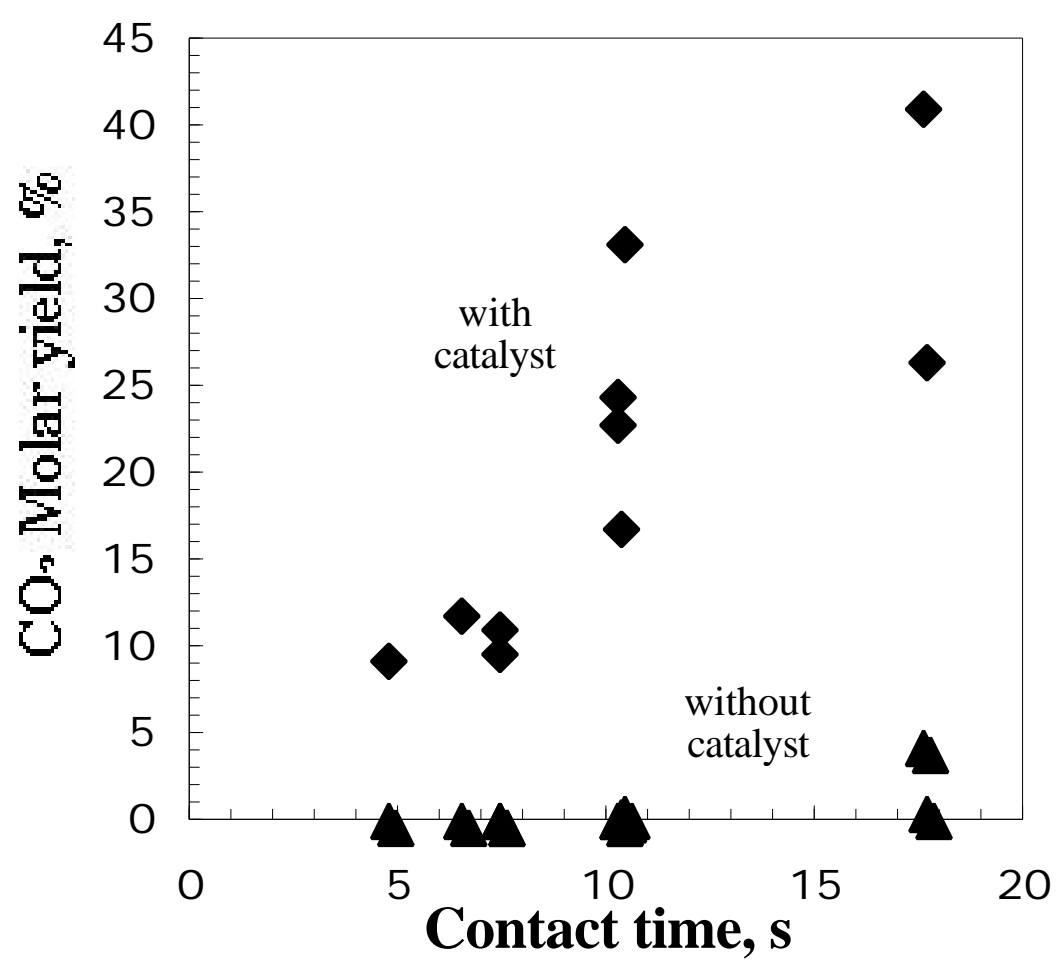

Fig. 2: Comparison of the $\mathrm{CO}_{2}$ molar yield with $\mathrm{MnO}_{2}$ and without $\mathrm{MnO}_{2}$

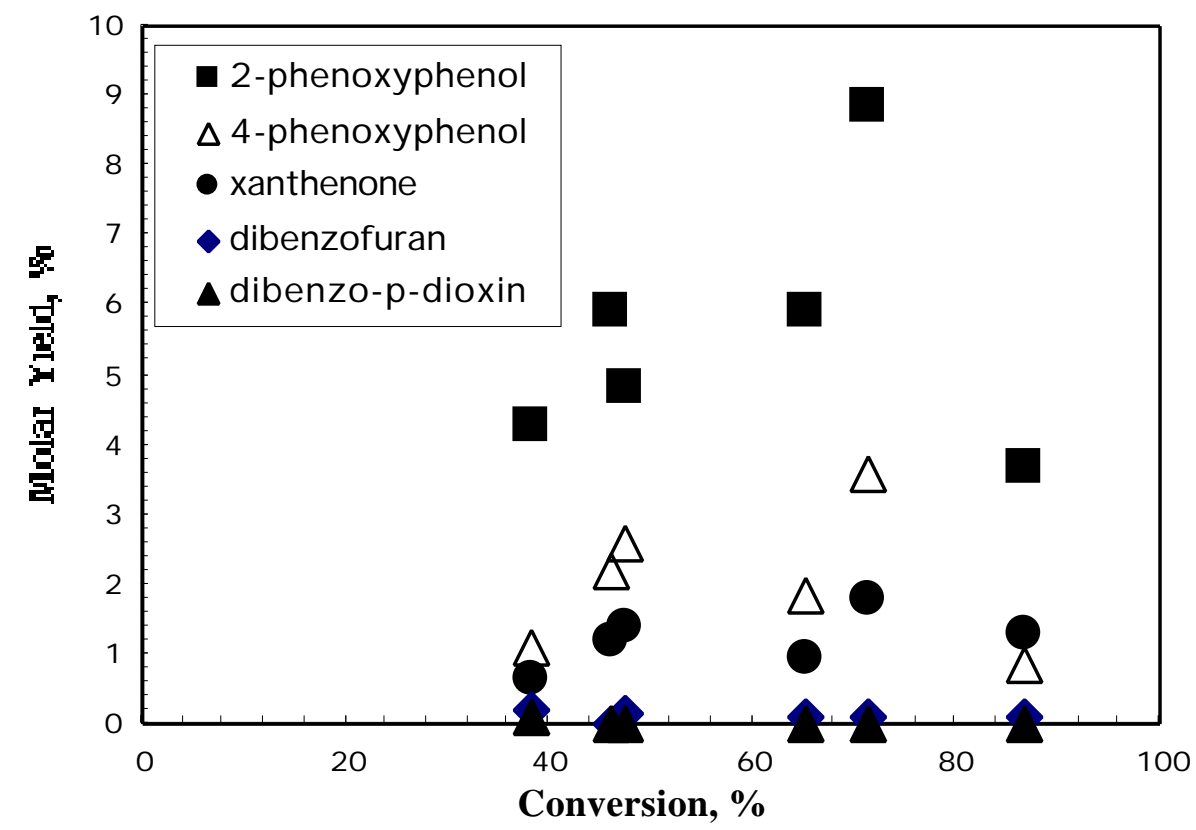

Fig. 3: The molar yield of the major by-products at different phenol conversion 


\section{Reaction Kinetics}

We took two different approaches for correlating the kinetics. The first was to use a conventional power law rate equation such as:

$$
\text { rate }=-k[\mathrm{PhOH}]^{a}\left[\mathrm{O}_{2}\right]^{b}\left[\mathrm{H}_{2} \mathrm{O}\right]^{c}
$$

Where $\mathrm{k}$ is the rate constant which can be expressed as in Eq. (2), and a, b, and c are global reaction orders for phenol, oxygen and water, respectively. The second approach, which we consider next, is to use a Langmuir-Hinshelwood rate law.

$$
k(T)=A \exp \left(-\frac{E_{a}}{R T}\right)
$$

The conversion of phenol, $X$, is:

$$
X=1-\frac{F_{\text {PhOH }}}{F_{\text {PhOH }}}
$$

Where $\mathrm{F} P \mathrm{PH}_{\text {is }}$ is the molar flow rate of phenol.

The design equation for a catalytic isothermal, isobaric, plug-flow reactor is given as

$$
\text { rate }=-F_{\text {PhOHo }_{0}} \frac{d X}{d W}=-\frac{m[P h O H]_{0}}{\rho} \frac{d X}{d W}
$$

Where, $\mathrm{F}_{\mathrm{PhOH}, \mathrm{o}}$ is the phenol molar flow rate into the reactor, $\mathrm{mol} / \mathrm{s} ; \mathrm{m}$ is the total mass flow rate, $\mathrm{g} / \mathrm{s} ; \rho$ is the reaction medium density, $\mathrm{g} / \mathrm{L} ; \mathrm{W}$ is the mass of catalyst, g.

The catalyst contact time, $\tau$, is defined as the ratio of the catalyst mass to the total mass flow rate. The concentrations of oxygen and water can be assumed to maintain their initial values through the reaction because they are present in great excess. Combining Eq. (1)-(4), we obtain

$$
\frac{d X}{d \tau}=18 A \exp \left(-\frac{E_{a}}{R T}\right)[P h O H]_{0}^{a-1}\left[O_{2}\right]_{0}^{b}\left[H_{2} O\right]_{0}^{c+1}(1-X)^{a}
$$

Eq. (5) can be solved analytically with the initial condition $X=0$ at $\tau=0$ to provide Eq. (6) as the relationship between the phenol conversion and the relevant process variables.

$$
X=1-\left(1-18(1-a) k[\mathrm{PhOH}]_{0}^{a-1}\left[\mathrm{O}_{2}\right]_{0}^{b}\left[H_{2} O\right]_{0}^{c+1}\right)^{1 /(1-a)} \quad \text { if } \mathrm{a} \neq 1
$$

A non-linear regression analysis of the experimental data was applied to determine the parameters $\left(\mathrm{a}, \mathrm{b}, \mathrm{c}, \mathrm{A}\right.$, and $\left.\mathrm{E}_{\mathrm{a}}\right)$ in the power law rate equation. The reaction 
orders were found to $\mathrm{be} a=0.83, \mathrm{~b}=0.36$ and $\mathrm{c}=0$, respectively. The values of $\mathrm{A}$ and $\mathrm{E}_{\mathrm{a}}$ were $10^{0.30}\left(\mathrm{M}^{-0.19} \mathrm{~s}^{-1} \mathrm{Lg}^{-1}\right)$ and $48.3 \mathrm{~kJ} / \mathrm{mol}$, respectively.

We also obtained the formation rate equation for $\mathrm{CO}_{2}$ using the same procedure used for phenol disappearance.

$$
X_{C}=1-\left(1-18(1-a) k[\text { TOC }]_{0}^{a-1}\left[O_{2}\right]_{0}^{b}\left[H_{2} O\right]_{0}^{c+1} \tau\right)^{1 /(1-a)} \text { if } \quad a \neq 1
$$

Where, $\mathrm{X}_{\mathrm{C}}$ is the molar yield of $\mathrm{CO}_{2}$, which is equivalent to the disappearance of TOC (total organic carbon). [TOC]0 is the initial concentration of the total organic carbon, which is equal to $6[\mathrm{PhOH}]_{0}$. The parameters $\left(\mathrm{a}, \mathrm{b}, \mathrm{c}, \mathrm{A}\right.$, and $\left.\mathrm{E}_{\mathrm{a}}\right)$ can be determined by using non-linear regression methods as $0.54,0.94,0,10^{6.4}\left(\mathrm{M}^{-0.48} \mathrm{~s}^{-}\right.$ ${ }^{1} \mathrm{Lg}^{-1}$ ), and $120 \mathrm{~kJ} / \mathrm{mol}$, respectively.

We now turn our attention to Langmuir-Hinshelwood rate equations, which are based on the reactants adsorbing onto distinct catalytic sites. We can develop potential rate equations by assuming that phenol and oxygen adsorb on the same types of sites, or that phenol adsorbs on one type of site and oxygen adsorbs on a different type. Taking a surface reaction between adsorbed phenol and adsorbed oxygen as the rate-limiting step, we obtain Langmuir-Hinshelwood rate expressions in the following forms:

$$
\begin{aligned}
& \text { rate }=-\frac{k K_{1} K_{2}^{0.5}[\mathrm{PhOH}]\left[\mathrm{O}_{2}\right]^{0.5}}{\left(1+K_{1}[\mathrm{PhOH}]+K_{2}^{0.5}\left[\mathrm{O}_{2}\right]^{0.5}\right)^{2}} \\
& \text { rate }=-\frac{k K_{1} K_{2}^{0.5}[\mathrm{PhOH}]\left[\mathrm{O}_{2}\right]^{0.5}}{\left(1+K_{1}[\mathrm{PhOH}]\right)\left(1+K_{2}^{0.5}\left[\mathrm{O}_{2}\right]^{0.5}\right)}
\end{aligned}
$$

Where, $\mathrm{k}$ is the apparent rate constant, mol/(gcat.s); and $\mathrm{K}_{1}$ and $\mathrm{K}_{2}$ are adsorption equilibrium constants for phenol and oxygen. The Arrhenius equation and the van't Hoff equation can be used to write the apparent rate constant and the adsorption equilibrium constants, respectively, as functions of temperature. A nonlinear regression method was used to determine the parameters. Eq. (9) gave the best fit between the experimental and the calculated conversions, which suggested that the active sites occupied by phenol are different from that occupied by oxygen species.

\subsection{CuO Catalyst}


In addition to experiments with $\mathrm{MnO}_{2}$, we have also initiated an extensive experimental campaign with a $\mathrm{CuO}$ catalyst supported on alumina. Table 3 provides the experimental results.

\section{M ass Transport Influence}

We once again used the Mears and Weisz-Prater criteria to test for possible mass transport intrusions on the measured reaction rates for this supported catalyst. These criteria revealed that the data obtained were free of any external mass transfer limitations but were affected by internal mass transfer limitations. Discovering the presence of these pore diffusion limitations, we decided to defer the kinetics analysis until new data could be obtained that were free from these limitations. We are currently conducting a new set of experiments with smaller catalysts particles in an attempt to measure the intrinsic kinetics of oxidation over this supported catalyst.

\section{Table 3: Summary of Catalytic Phenol oxidation over $\mathrm{CuO} / \mathrm{Al}_{2} \mathrm{O}_{3}$ in SCW}

\begin{tabular}{cccccccccc}
$\begin{array}{c}\text { Reaction Reaction } \\
\begin{array}{c}\text { Pressure Temp. } \\
(\text { atm })\end{array}\end{array}$ & $\begin{array}{c}\text { W/FA0 } \\
\left({ }^{\circ} \mathrm{C}\right)\end{array}$ & $\begin{array}{c}\text { PhOH } \\
\text { (kgcat- } \\
\text { s/mmol) }\end{array}$ & $\begin{array}{c}\text { Wonc. } \\
(\mathrm{mmol} / \mathrm{L})\end{array}$ & $\begin{array}{c}\text { Conc. } \\
(\mathrm{mol} / \mathrm{L})\end{array}$ & $\begin{array}{c}\text { Oxygen } \\
\text { Conc. } \\
(\mathrm{mmol} / \mathrm{L})\end{array}$ & $\begin{array}{c}\mathrm{PhOH} \\
\text { Conv. } \\
(\%)\end{array}$ & $\begin{array}{c}\mathrm{CO} \\
\text { Yield } \\
(\%)\end{array}$ & $\begin{array}{c}\mathrm{CO}_{2} \\
\text { Yield } \\
(\%)\end{array}$ & $\begin{array}{c}\text { Carbon } \\
\text { Tally } \\
(\%)\end{array}$ \\
\hline 250 & 381 & 12.10 & 0.56 & 24.99 & 27.77 & 84 & 1.1 & 50 & 67 \\
250 & 381 & 8.53 & 0.57 & 25.07 & 27.53 & 86 & 1.2 & 42 & 57 \\
250 & 380 & 6.85 & 0.57 & 25.38 & 28.22 & 79 & 1.3 & 35 & 57 \\
250 & 381 & 6.22 & 1.47 & 25.15 & 27.97 & 94 & 1.1 & 44 & 52 \\
250 & 381 & 3.98 & 1.46 & 24.99 & 27.90 & 80 & 1.3 & 36 & 58 \\
250 & 381 & 2.71 & 1.57 & 25.07 & 25.90 & 79 & 1.1 & 27 & 50 \\
250 & 381 & 2.23 & 1.55 & 25.15 & 26.50 & 75 & 1.0 & 24 & 50 \\
250 & 381 & 1.52 & 2.42 & 25.07 & 28.11 & 72 & 1.0 & 24 & 52 \\
& & & & & & & & & \\
250 & 381 & 1.53 & 2.69 & 25.15 & 25.12 & 76 & 1.0 & 23 & 48 \\
250 & 381 & 2.36 & 2.43 & 24.91 & 27.56 & 80 & 1.4 & 31 & 52 \\
250 & 381 & 1.57 & 2.02 & 25.07 & 17.08 & 78 & 0.0 & 37 & 59 \\
250 & 381 & 2.42 & 1.88 & 25.23 & 18.67 & 80 & 0.6 & 60 & 81 \\
250 & 381 & 2.78 & 2.00 & 24.91 & 17.03 & 79 & 1.0 & 44 & 66 \\
250 & 380 & 4.16 & 2.01 & 25.30 & 17.58 & 88 & 0.8 & 51 & 63 \\
250 & 381 & 4.48 & 1.89 & 24.74 & 71.81 & 94 & 0.7 & 74 & 82 \\
250 & 381 & 2.79 & 2.01 & 24.82 & 67.91 & 89 & 0.0 & 58 & 70 \\
& & & & & & & & & \\
250 & 381 & 2.24 & 1.94 & 24.91 & 70.84 & 85 & 1.5 & 47 & 63 \\
250 & 381 & 1.81 & 1.92 & 24.82 & 71.26 & 81 & 1.5 & 38 & 59 \\
250 & 380 & 1.94 & 1.86 & 25.30 & 29.47 & 75 & 1.6 & 32 & 58 \\
250 & 381 & 2.12 & 2.01 & 24.99 & 26.69 & 79 & 1.5 & 33 & 55 \\
250 & 381 & 2.81 & 2.02 & 24.74 & 25.94 & 83 & 0.0 & 41 & 59 \\
219 & 382 & 1.53 & 2.02 & 9.05 & 25.38 & 63 & 1.2 & 29 & 67 \\
219 & 382 & 1.03 & 1.98 & 9.05 & 25.87 & 51 & 1.2 & 18 & 67 \\
219 & 381 & 0.83 & 1.90 & 9.07 & 27.29 & 40 & 1.5 & 11 & 71
\end{tabular}

Table 3(cont.) Summary of phenol oxidation over $\mathrm{CuO} / \mathrm{Al}_{2} \mathrm{O}_{3}$ in $\mathrm{SCW}$ 


\begin{tabular}{|c|c|c|c|c|c|c|c|c|c|}
\hline Reaction & Reaction & $\mathrm{W} / \mathrm{F}_{\mathrm{A} 0}$ & $\mathrm{PhOH}$ & Water & Oxygen & $\mathrm{PhOH}$ & $\mathrm{CO}$ & $\mathrm{CO}_{2}$ & Carbon \\
\hline $\begin{array}{c}\text { Pressure } \\
\text { (atm) }\end{array}$ & $\begin{array}{l}\text { Temp. } \\
\left({ }^{\circ} \mathrm{C}\right)\end{array}$ & $\begin{array}{l}\text { (kgcat- } \\
\text { s/mmol) }\end{array}$ & $\begin{array}{c}\text { Conc. } \\
(\mathrm{mmol} / \mathrm{L})\end{array}$ & $\begin{array}{l}\text { Conc. } \\
\text { (mol/L) }\end{array}$ & $\begin{array}{c}\text { Conc. } \\
(\mathrm{mmol} / \mathrm{L})\end{array}$ & $\begin{array}{l}\text { Conv. } \\
(\%)\end{array}$ & $\begin{array}{l}\text { Yield } \\
(\%)\end{array}$ & $\begin{array}{l}\text { Yield } \\
(\%)\end{array}$ & $\begin{array}{c}\text { Tally } \\
(\%)\end{array}$ \\
\hline 219 & 381 & 0.65 & 1.92 & 9.10 & 27.12 & 30 & 0.0 & 11 & 81 \\
\hline 219 & 381 & 0.55 & 1.96 & 9.30 & 27.70 & 27 & 1.0 & 5 & 78 \\
\hline 273 & 380 & 5.29 & 2.03 & 28.02 & 26.96 & 94 & 0.9 & 72 & 79 \\
\hline 273 & 380 & 3.50 & 2.05 & 28.09 & 26.83 & 91 & 0.8 & 50 & 61 \\
\hline 273 & 380 & 2.75 & 1.93 & 28.05 & 28.47 & 85 & 0.8 & 42 & 58 \\
\hline 273 & 380 & 2.14 & 2.00 & 28.17 & 27.79 & 82 & 0.8 & 35 & 54 \\
\hline 300 & 381 & 5.44 & 2.16 & 29.70 & 25.06 & 97 & 0.0 & 66 & 71 \\
\hline 300 & 380 & 3.94 & 2.04 & 29.81 & 26.99 & 94 & 1.2 & 59 & 67 \\
\hline 300 & 380 & 2.94 & 2.02 & 29.84 & 27.28 & 88 & 1.5 & 51 & 65 \\
\hline 300 & 381 & 2.31 & 1.97 & 29.70 & 27.77 & 83 & 1.5 & 40 & 59 \\
\hline 250 & 380 & 14.20 & 0.67 & 25.30 & 53.75 & 100 & 1.3 & 45 & 45 \\
\hline 250 & 381 & 4.73 & 1.50 & 25.07 & 40.17 & 98 & 0.0 & 47 & 51 \\
\hline 250 & 381 & 2.56 & 2.12 & 25.23 & 30.80 & 86 & 1.3 & 43 & 57 \\
\hline 250 & 380 & 5.58 & 1.10 & 25.30 & 47.01 & 97 & 1.7 & 45 & 50 \\
\hline 250 & 381 & 4.10 & 1.34 & 24.99 & 42.34 & 87 & 1.8 & 48 & 63 \\
\hline 250 & 381 & 2.64 & 1.77 & 25.07 & 35.92 & 81 & 1.5 & 37 & 57 \\
\hline 250 & 381 & 1.98 & 2.05 & 24.99 & 31.29 & 78 & 0.2 & 33 & 56 \\
\hline 250 & 400 & 7.42 & 0.42 & 9.58 & 17.76 & 90 & 0.0 & 59 & 71 \\
\hline 250 & 400 & 2.64 & 0.79 & 9.60 & 11.97 & 65 & 0.0 & 39 & 75 \\
\hline 250 & 400 & 6.49 & 0.38 & 9.56 & 18.24 & 80 & 0.0 & 53 & 75 \\
\hline 250 & 400 & 3.80 & 0.56 & 9.56 & 15.52 & 68 & 0.0 & 43 & 77 \\
\hline 250 & 400 & 2.52 & 0.71 & 9.56 & 13.13 & 59 & 0.0 & 33 & 75 \\
\hline 250 & 400 & 2.01 & 0.80 & 9.56 & 11.76 & 50 & 0.0 & 28 & 80 \\
\hline 250 & 421 & 6.72 & 0.34 & 7.46 & 13.54 & 87 & 0.0 & 64 & 80 \\
\hline 250 & 421 & 3.71 & 0.51 & 7.46 & 11.00 & 72 & $\overline{0.0}$ & 51 & 81 \\
\hline 250 & 421 & 2.65 & 0.61 & 7.49 & 9.46 & 62 & 0.0 & 42 & 83 \\
\hline 250 & 421 & 7.15 & 0.26 & 7.49 & 14.86 & 80 & 0.0 & 58 & 82 \\
\hline 250 & 421 & 4.00 & 0.40 & 7.48 & 12.66 & 66 & 0.0 & 46 & 83 \\
\hline 250 & 421 & 2.76 & 0.51 & 7.48 & 11.02 & 55 & 0.0 & 37 & 85 \\
\hline 250 & 421 & 2.07 & 0.60 & 7.48 & 9.67 & 49 & 0.0 & 30 & 84 \\
\hline 250 & 451 & 6.44 & 0.30 & 6.15 & 10.95 & 98 & 0.0 & 77 & 83 \\
\hline 250 & 451 & 3.83 & 0.42 & 6.15 & 9.10 & 88 & 0.0 & 69 & 86 \\
\hline 250 & 451 & 2.59 & 0.51 & 6.15 & 7.58 & 79 & 0.0 & 59 & 84 \\
\hline 250 & 451 & 7.18 & 0.22 & 6.16 & 12.16 & 96 & 0.0 & 87 & 98 \\
\hline 250 & 451 & 3.90 & 0.34 & 6.16 & 10.25 & 84 & 0.0 & 71 & 92 \\
\hline 250 & 451 & 2.72 & 0.43 & 6.16 & 8.91 & 76 & 0.0 & 60 & 90 \\
\hline 250 & 451 & 2.01 & 0.50 & 6.15 & 7.73 & 68 & 0.0 & 50 & 86 \\
\hline 219 & 381 & 6.43 & 0.44 & 9.23 & 16.29 & 60 & 0.0 & 40 & 82 \\
\hline 219 & 381 & 4.53 & 0.56 & 9.20 & 14.45 & 63 & 0.0 & 26 & 64 \\
\hline 219 & 381 & 6.28 & 0.38 & 9.23 & 17.24 & 55 & 0.0 & 34 & 81 \\
\hline 219 & 381 & 4.85 & 0.46 & 9.23 & 16.04 & 52 & 0.0 & 28 & 78 \\
\hline 219 & 380 & 2.00 & 0.79 & 9.45 & 11.43 & 37 & 0.0 & 14 & 78 \\
\hline 239 & 381 & 6.46 & 1.01 & 21.26 & 37.44 & 79 & 0.0 & 46 & 68 \\
\hline
\end{tabular}

Table 3(cont.) Summary of phenol oxidation over $\mathrm{CuO} / \mathrm{Al}_{2} \mathrm{O}_{3}$ in $\mathrm{SCW}$ 


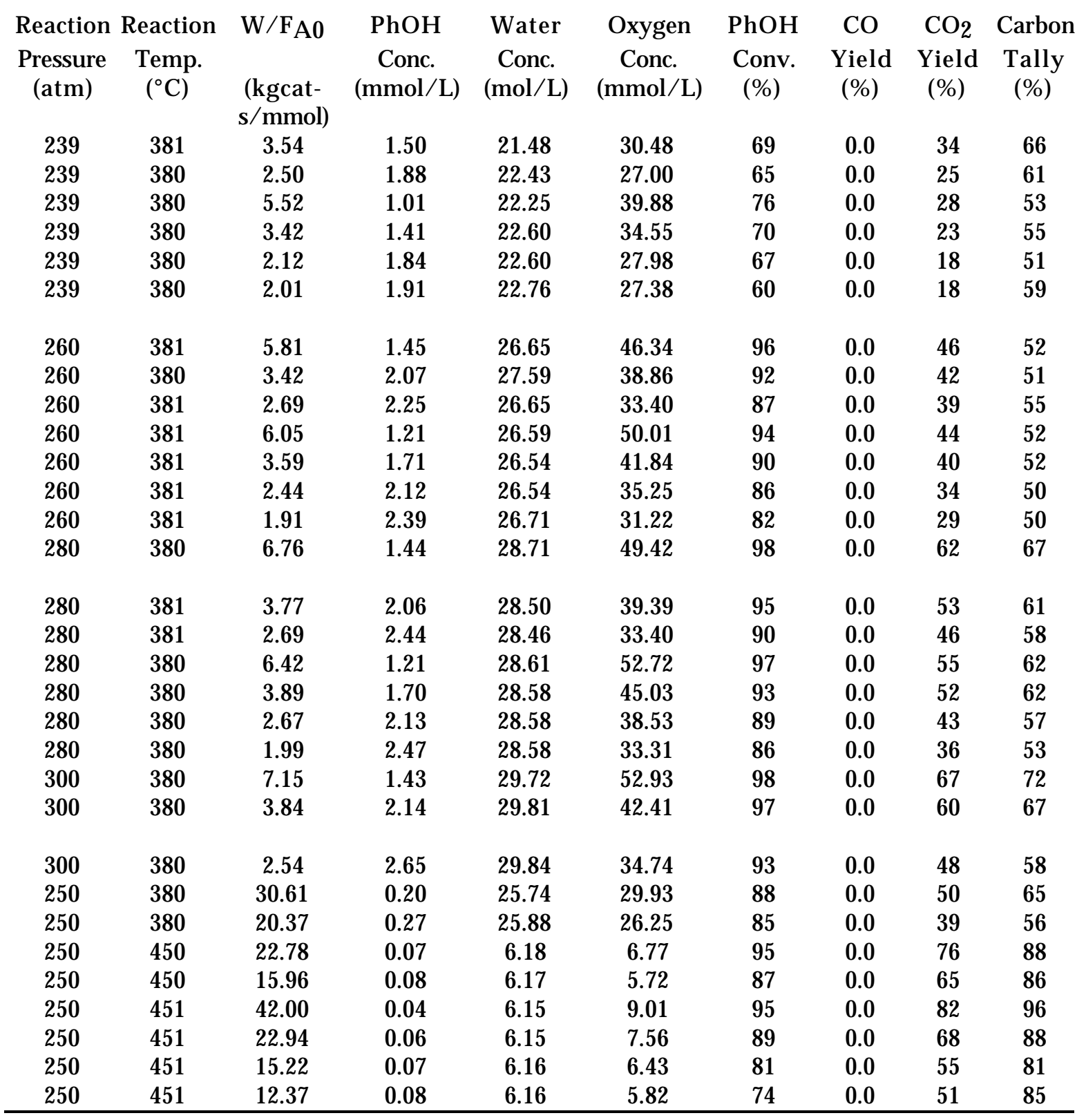

\section{4 $\mathrm{TiO}_{2}$ Catalyst}

The final catalytic material we used is $\mathrm{TiO}_{2}$. Results for catalytic SCWO with this bulk transition metal oxide appear in Table 4 . We provide the phenol conversion, the molar yields of $\mathrm{CO}$ and $\mathrm{CO}_{2}$, and the sum of the yields of phenol, $\mathrm{CO}$, and $\mathrm{CO}_{2}$, which we refer to as the carbon tally, for each experiment. The carbon tally is not a carbon balance. Its values being less than $100 \%$ simply means that organic products of incomplete oxidation were formed. The main gaseous product is $\mathrm{CO}_{2}$ but small amounts of $\mathrm{CO}(<8 \%$ yield) are also formed.

The $\mathrm{TiO}_{2}$ catalyst increased the phenol conversion and the $\mathrm{CO}_{2}$ yield relative to those obtained without a catalyst. We next consider the issue of the $\mathrm{CO}_{2}$ selectivity. 
Here we define selectivity as the product yield divided by the phenol conversion. The $\mathrm{CO}_{2}$ selectivity is relevant because SCWO of complex organic compounds such as phenol proceeds through a series of steps that produces products of incomplete oxidation. It is desirable for a catalyst to reduce the yields of these products and increase the yield of $\mathrm{CO}_{2}$. The selectivities to $\mathrm{CO}_{2}$ observed experimentally from catalytic SCWO over $\mathrm{TiO}_{2}$ are higher than the $\mathrm{CO}_{2}$ selectivities anticipated for noncatalytic SCWO at the same phenol conversion, which indicates that the use of the $\mathrm{TiO}_{2}$ catalyst can increase the $\mathrm{CO}_{2}$ selectivity. Taken collectively, our data show that the $\mathrm{TiO}_{2}$ catalyst enhances the rates of phenol conversion and $\mathrm{CO}_{2}$ formation, and also increases $\mathrm{CO}_{2}$ selectivity.

Before embarking on a kinetics analysis, we first used the Mears and Weisz-Prater criteria to verify that mass transfer limitations were negligible. We then used a non-linear regression analysis to fit the experimental phenol conversions in Table 4 to Eq. (6) and thereby to determine the parameters $\left(a, b, A\right.$, and $\left.E_{a}\right)$ in the power-law rate equation. The reaction orders we obtained are $a=0.68$, and $b=0.15$, respectively. The values of the Arrhenius parameters $A$ and $E_{a}$ are $10^{5.33}\left(\mathrm{M}^{-0.17} \mathrm{~s}^{-1} \mathrm{Lg}^{-1}\right)$ and 129 $\mathrm{kJ} / \mathrm{mol}$, respectively. We have also analyzed the kinetics of $\mathrm{CO}_{2}$ formation during phenol catalytic oxidation over $\mathrm{TiO}_{2}$ in supercritical water. The quantitative kinetics analysis is similar to that described above for phenol conversion. The parameters $\left(\mathrm{a}, \mathrm{b}, \mathrm{A}\right.$, and $\left.\mathrm{E}_{\mathrm{a}}\right)$ that best fit the data are $0.59,0.01,10^{4.8}\left(\mathrm{M}^{-0.4} \mathrm{~s}^{-1} \mathrm{Lg}^{-1}\right)$, and $131 \mathrm{~kJ} / \mathrm{mol}$, respectively. We also fit the phenol disappearance data to a LangmuirHinshelwood rate equation and found that a model wherein the active sites occupied by phenol are different than those occupied by oxygen atoms provided a better fit of the data. We are currently doing additional analyses of the $\mathrm{TiO}_{2}$ data and plan to submit a manuscript for publication before the end of 1999. 
Table 4. Summary of Phenol oxidation over $\mathrm{TiO}_{2}$ in SCW

\begin{tabular}{|c|c|c|c|c|c|c|c|c|c|}
\hline $\begin{array}{c}\text { Reaction } \\
\text { Pressure } \\
(\text { atm) }\end{array}$ & $\begin{array}{l}\text { Reaction } \\
\text { Temp. } \\
\left({ }^{\circ} \mathrm{C}\right)\end{array}$ & $\begin{array}{l}\text { W/FA0 } \\
\text { (kgcat- } \\
\text { s/mmol) }\end{array}$ & $\begin{array}{c}\mathrm{PhOH} \\
\text { Conc. } \\
\text { (mmol/L) }\end{array}$ & $\begin{array}{c}\text { Water } \\
\text { Conc. } \\
(\mathrm{mol} / \mathrm{L})\end{array}$ & $\begin{array}{l}\text { Oxygen } \\
\text { Conc. } \\
\text { (mmol/L) }\end{array}$ & $\begin{array}{c}\mathrm{PhOH} \\
\text { Conv. } \\
(\%)\end{array}$ & $\begin{array}{c}\mathrm{CO} \\
\text { Yield } \\
(\%)\end{array}$ & $\begin{array}{c}\mathrm{CO}_{2} \\
\text { Yield } \\
(\%)\end{array}$ & $\begin{array}{c}\text { Carbon } \\
\text { Tally } \\
(\%)\end{array}$ \\
\hline 250 & 381 & 19.74 & 0.73 & 25.15 & 24.05 & 70 & 2.7 & 25 & 58 \\
\hline 250 & 381 & 14.82 & 0.68 & 24.99 & 25.87 & 71 & 2.1 & 21 & 53 \\
\hline 250 & 381 & 11.25 & 0.69 & 25.23 & 25.92 & 53 & 1.3 & 16 & 64 \\
\hline 250 & 381 & 9.24 & 0.69 & 25.15 & 25.89 & 42 & 1.6 & 13 & 72 \\
\hline 250 & 381 & 9.74 & 1.96 & 24.82 & 33.20 & 69 & 2.3 & 21 & 55 \\
\hline 250 & 381 & 5.25 & 2.78 & 24.99 & 25.33 & 47 & 1.3 & 17 & 71 \\
\hline 250 & 381 & 7.07 & 1.89 & 24.82 & 33.89 & 50 & 1.2 & 15 & 67 \\
\hline 250 & 381 & 5.43 & 1.89 & 24.99 & 34.27 & 63 & 1.1 & 12 & 51 \\
\hline 250 & 381 & 2.34 & 2.72 & 25.07 & 26.10 & 30 & 0.6 & 7 & 78 \\
\hline 250 & 381 & 7.19 & 1.97 & 24.66 & 16.54 & 44 & 1.0 & 14 & 71 \\
\hline 250 & 381 & 5.05 & 1.96 & 24.74 & 16.77 & 39 & 0.5 & 8 & 70 \\
\hline 250 & 381 & 3.93 & 1.93 & 24.74 & 16.99 & 30 & 0.5 & 8 & 79 \\
\hline 250 & 381 & 3.19 & 1.95 & 24.99 & 17.17 & 24 & 0.3 & 7 & 83 \\
\hline 250 & 381 & 7.33 & 1.92 & 25.07 & 26.84 & 49 & 1.7 & 14 & 67 \\
\hline 250 & 381 & 4.87 & 1.97 & 24.91 & 25.70 & 38 & 1.2 & 11 & 74 \\
\hline 250 & 381 & 3.89 & 1.94 & 25.15 & 26.68 & 34 & 0.7 & 8 & 74 \\
\hline 250 & 381 & 3.19 & 1.95 & 25.23 & 26.79 & 30 & 0.6 & 8 & 79 \\
\hline 250 & 381 & 6.99 & 2.02 & 25.07 & 49.82 & 49 & 1.8 & 21 & 73 \\
\hline 250 & 381 & 5.06 & 1.97 & 25.07 & 51.15 & 45 & 1.3 & 18 & 74 \\
\hline 250 & 381 & 3.89 & 1.98 & 25.15 & 51.39 & 36 & 0.8 & 12 & 77 \\
\hline 250 & 381 & 3.11 & 1.99 & 25.07 & 50.64 & 34 & 0.5 & 11 & 78 \\
\hline 219 & 380 & 3.00 & 2.14 & 9.36 & 24.49 & 49 & 1.2 & 12 & 64 \\
\hline 219 & 380 & 1.98 & 1.97 & 9.36 & 26.87 & 31 & 0.5 & 7 & 76 \\
\hline 219 & 380 & 1.45 & 1.99 & 9.39 & 26.77 & 27 & 0.3 & 5 & 78 \\
\hline 219 & 380 & 1.22 & 1.96 & 9.48 & 27.72 & 23 & 0.2 & 4 & 81 \\
\hline 273 & 380 & 10.44 & 2.02 & 28.09 & 26.10 & 72 & 1.9 & 26 & 56 \\
\hline 273 & 380 & 6.26 & 2.05 & 28.09 & 25.70 & 55 & 1.1 & 16 & 62 \\
\hline 277 & 380 & 4.91 & 2.01 & 28.40 & 26.87 & 44 & 1.0 & 13 & 70 \\
\hline 280 & 380 & 3.83 & 2.03 & 28.58 & 26.85 & 36 & 0.8 & 11 & 77 \\
\hline 300 & 380 & 11.62 & 1.98 & 29.81 & 26.64 & 74 & 1.5 & 30 & 58 \\
\hline 300 & 380 & 6.93 & 2.08 & 29.79 & 25.27 & 62 & 1.2 & 20 & 58 \\
\hline 300 & 380 & 5.19 & 2.04 & 29.81 & 25.79 & 51 & 1.0 & 16 & 65 \\
\hline 300 & 380 & 4.22 & 2.00 & 29.76 & 26.28 & 46 & 0.7 & 14 & 69 \\
\hline 250 & 381 & 6.51 & 1.75 & 24.99 & 36.70 & 60 & 1.2 & 16 & 58 \\
\hline 250 & 381 & 4.58 & 2.11 & 24.93 & 31.07 & 47 & 0.8 & 13 & 67 \\
\hline 250 & 381 & 6.24 & 1.53 & 25.00 & 40.09 & 53 & 0.8 & 15 & 63 \\
\hline 250 & 381 & 4.84 & 1.78 & 24.93 & 36.15 & 52 & 0.8 & 12 & 62 \\
\hline 250 & 381 & 3.60 & 2.11 & 25.17 & 31.76 & 35 & 0.6 & 10 & 76 \\
\hline 250 & 400 & 11.13 & 0.50 & 9.59 & 17.18 & 53 & 2.1 & 23 & 72 \\
\hline 250 & 400 & 7.18 & 0.66 & 9.59 & 14.66 & 39 & 1.7 & 20 & 83 \\
\hline 250 & 400 & 4.67 & 0.83 & 9.54 & 11.93 & 29 & 1.1 & 14 & 86 \\
\hline 250 & 400 & 10.46 & 0.43 & 9.59 & 18.23 & 57 & 1.9 & 24 & 69 \\
\hline 250 & 400 & 7.20 & 0.56 & 9.55 & 16.18 & 35 & 1.6 & 18 & 85 \\
\hline
\end{tabular}


Final Technical Report

Table 4. (cont.) Summary of Phenol oxidation over $\mathrm{TiO}_{2}$ in $\mathrm{SCW}$

\begin{tabular}{|c|c|c|c|c|c|c|c|c|c|}
\hline $\begin{array}{c}\text { Reaction } \\
\text { Pressure } \\
\text { (atm) }\end{array}$ & $\begin{array}{l}\text { Reaction } \\
\text { Temp } \\
\left({ }^{\circ} \mathrm{C}\right)\end{array}$ & $\begin{array}{l}\text { (kgcat- } \\
\text { s/mmol) }\end{array}$ & $\begin{array}{c}\mathrm{PhOH} \\
\text { Conc. } \\
\text { (mmol/L) }\end{array}$ & $\begin{array}{l}\text { Water } \\
\text { Conc. } \\
\text { (mol/L) }\end{array}$ & $\begin{array}{l}\text { Oxygen } \\
\text { Conc. } \\
\text { (mmol/L) }\end{array}$ & $\begin{array}{c}\mathrm{PhOH} \\
\text { Conv. } \\
(\%)\end{array}$ & $\begin{array}{c}\mathrm{CO} \\
\text { Yield } \\
(\%)\end{array}$ & $\begin{array}{c}\mathrm{CO}_{2} \\
\text { Yield } \\
(\%)\end{array}$ & $\begin{array}{l}\text { Carbon } \\
\text { Tally } \\
(\%)\end{array}$ \\
\hline 250 & 400 & 4.72 & 0.72 & 9.56 & 13.67 & 31 & 1.1 & 12 & 82 \\
\hline 250 & 400 & 3.55 & 0.83 & 9.58 & 11.93 & 23 & 0.9 & 9 & 87 \\
\hline 250 & 421 & 11.12 & 0.39 & 7.42 & 14.47 & 82 & 3.9 & 39 & 61 \\
\hline 250 & 421 & 6.98 & 0.52 & 7.43 & 12.24 & 61 & 3.4 & 32 & 74 \\
\hline 250 & 421 & 4.77 & 0.64 & 7.42 & 10.26 & 47 & 2.7 & 24 & 79 \\
\hline 250 & 422 & 11.57 & 0.31 & 7.40 & 15.63 & 78 & 3.8 & 38 & 63 \\
\hline 250 & 421 & 6.36 & 0.47 & 7.42 & 12.98 & 62 & 3.0 & 28 & 69 \\
\hline 250 & 421 & 4.74 & 0.56 & 7.42 & 11.49 & 49 & 2.5 & 24 & 77 \\
\hline 250 & 421 & 3.50 & 0.66 & 7.42 & 9.90 & 38 & 2.0 & 17 & 81 \\
\hline 250 & 440 & 12.31 & 0.32 & 6.50 & 12.00 & 97 & 6.3 & 54 & 63 \\
\hline 250 & 440 & 6.91 & 0.46 & 6.52 & 9.82 & 85 & 5.8 & 44 & 65 \\
\hline 250 & 441 & 4.58 & 0.57 & 6.48 & 8.05 & 73 & 4.7 & 35 & 67 \\
\hline 250 & 441 & 14.00 & 0.23 & 6.48 & 13.28 & 94 & 7.6 & 59 & 72 \\
\hline 250 & 441 & 7.17 & 0.38 & 6.49 & 11.06 & 83 & 5.9 & 46 & 69 \\
\hline 250 & 441 & 4.91 & 0.47 & 6.49 & 9.55 & 70 & 4.9 & 36 & 71 \\
\hline 250 & 441 & 3.68 & 0.55 & 6.50 & 8.35 & 61 & 4.1 & 29 & 73 \\
\hline 250 & 440 & 13.57 & 0.20 & 6.49 & 13.73 & 91 & 6.4 & 55 & 69 \\
\hline 219 & 381 & 24.51 & 0.26 & 9.11 & 15.24 & 43 & 2.6 & 14 & 74 \\
\hline 219 & 381 & 6.76 & 0.66 & 9.20 & 12.71 & 23 & 1.4 & 6 & 84 \\
\hline 219 & 381 & 4.53 & 0.81 & 9.20 & 15.53 & 14 & 1.0 & 4 & 92 \\
\hline 219 & 381 & 13.55 & 0.33 & 9.19 & 17.25 & 12 & 2.0 & 11 & 101 \\
\hline 219 & 381 & 6.71 & 0.55 & 9.17 & 14.85 & 11 & 1.1 & 7 & 97 \\
\hline 219 & 381 & 4.64 & 0.69 & 9.20 & 13.00 & 9 & 0.8 & 5 & 97 \\
\hline 219 & 381 & 3.49 & 0.80 & 9.22 & 25.22 & 7 & 0.6 & 4 & 97 \\
\hline 239 & 382 & 10.88 & 1.03 & 19.12 & 37.89 & 41 & 1.8 & 14 & 75 \\
\hline 239 & 381 & 6.33 & 1.50 & 19.97 & 32.16 & 27 & 1.0 & 8 & 83 \\
\hline 239 & 381 & 4.45 & 1.74 & 19.43 & 26.32 & 22 & 0.9 & 7 & 85 \\
\hline 239 & 381 & 10.91 & 0.87 & 19.69 & 42.33 & 37 & 3.0 & 13 & 79 \\
\hline 239 & 381 & 6.45 & 1.22 & 19.42 & 35.33 & 27 & 1.2 & 9 & 84 \\
\hline 239 & 381 & 4.38 & 1.55 & 19.70 & 30.45 & 22 & 1.3 & 6 & 85 \\
\hline 239 & 381 & 3.47 & 1.75 & 19.71 & 27.11 & 22 & 0.5 & 5 & 84 \\
\hline 260 & 382 & 10.80 & 1.39 & 26.07 & 70.37 & 64 & 2.7 & 18 & 56 \\
\hline 260 & 381 & 6.40 & 1.94 & 26.19 & 58.13 & 46 & 1.6 & 12 & 67 \\
\hline 260 & 381 & 4.57 & 2.32 & 26.26 & 49.60 & 37 & 1.3 & 9 & 74 \\
\hline 260 & 380 & 12.37 & 1.07 & 26.73 & 80.33 & 54 & 2.6 & 20 & 68 \\
\hline 260 & 380 & 7.12 & 1.59 & 26.74 & 68.45 & 40 & 2.0 & 12 & 74 \\
\hline 260 & 381 & 4.53 & 2.06 & 26.53 & 56.56 & 34 & 1.5 & 9 & 76 \\
\hline 260 & 381 & 3.45 & 2.38 & 26.64 & 49.69 & 32 & 0.9 & 7 & 76 \\
\hline
\end{tabular}




\section{CONCLUSION}

Our results are providing the rate equations needed to analyze and design catalytic SCWO systems. In addition to this engineering utility, our results are also showing the potential that catalytic SCWO might have for completely oxidizing phenol at relatively mild conditions, perhaps at temperatures just above $\mathrm{Tc}_{\mathrm{c}}\left(374^{\circ} \mathrm{C}\right)$ instead of at over $600^{\circ} \mathrm{C}$, which is proposed to treat organic waste by non-catalytic SCWO.

The CARULITE 150 catalyst effectively promotes complete oxidation of phenol under SCWO conditions. Although external mass transfer did not influence the phenol conversion kinetics, the CARULITE 150 catalyst was so active that internal mass transfer did limit the kinetics. A kinetics analysis of the experimental data, which employed first-order rate laws and the internal effectiveness factor, resulted in intrinsic activation energies of 30.7 and $46.9 \mathrm{kcal} / \mathrm{mol}$ for the rate constants for phenol conversion and $\mathrm{CO}_{2}$ formation, respectively.

Bulk $\mathrm{MnO}_{2}$ was used as a catalyst for phenol oxidation in supercritical water. The phenol conversion and $\mathrm{CO}_{2}$ molar yield from this catalytic supercritical water oxidation are much higher than those from conventional non-catalytic SCWO of phenol under identical processing conditions. The selectivities to $\mathrm{CO}_{2}$ and to phenol dimers, however, appeared to be essentially the same functions of conversion for both catalytic and non-catalytic SCWO. Thus, the mechanism for product formation for catalytic SCWO is likely very similar to that for non-catalytic SCWO, with the key difference being the role of the catalyst in accelerating the rate of generation of reactive intermediates (phenoxy radicals). These reactive intermediates then return to the fluid phase where homogeneous oxidation chemistry prevails. The rate of phenol disappearance over $\mathrm{MnO}_{2}$ was consistent with a power-law rate equation that is 0.83 order in phenol, 0.36 order in $\mathrm{O}_{2}$, and zero order in water. The rate of disappearance of total organic carbon (TOC) exhibited reaction orders of 0.54 for the TOC concentration, 0.94 for the oxygen concentration, and zero for the water concentration. The catalytic kinetics for phenol disappearance were also consistent with a Langmuir-Hinshelwood rate law derived from a dual-site mechanism comprising the following steps: reversible adsorption of phenol on one type of catalytic site, reversible dissociative adsorption of oxygen on a different type of site, and irreversible, rate-determining surface reaction between adsorbed phenol and adsorbed oxygen.

In the presence of bulk $\mathrm{TiO}_{2}$ catalyst, the phenol disappearance and $\mathrm{CO}_{2}$ formation rates can be enhanced during SCWO, and the selectivities to $\mathrm{CO}_{2}$ and to the phenol dimers can be decreased at a given phenol conversion. The role of the $\mathrm{TiO}_{2}$ catalyst appears to be accelerating the rate of formation of phenoxy radicals, which then react in the fluid phase by the same mechanism operative for non-catalytic SCWO of phenol. The rates of phenol disappearance and $\mathrm{CO}_{2}$ formation are sensitive to the phenol and $\mathrm{O}_{2}$ concentrations, but insensitive to the water density. Both power-law 
and dual site Langmuir-Hinshelwood-Hougen-Watson rate laws can describe the catalytic kinetics.

\section{REFERENCES}

Aki, S. N. V. K.; Abraham, M. A. Environ. Prog. 1998, 17, 246.

Ding, Z.; Aki, S. N. V. K.; Abraham, M. A. In A CS Symp. Series; Hutchenson, K. W.,

Foster, N. R., Eds.; Am. Chem. Soc.: Wash., DC, 1995, Vol. 628, p232.

Ding, Z.; Frisch, M. A.; Li, L.; Gloyna, E. F. Ind. Eng. Chem. Res. 1996, 35, 3257.

Fogler, H. S. Elements of Chemical Reaction Engineering. $3^{\text {rd }}$ ed.; Prentice-Hall, Englewood Cliffs, NJ, 1998

Gopalan, S.; Savage, P. E. AIChE J. 1995, 41, 1864.

Jevtitch, M. M.; Bhattacharyya, D. Env. Prog. 1986, 5, 130.

Jin, L.; Ding, Z.Y.; Abraham, M.A. Chem. Eng. Sci., 1992, 47, 2659.

Krajnc, M.; Levec, J. A ppl. Catal. B: Environ. 1994, 3, L101.

Krajnc, M.; Levec, J. Ind. Eng. Chem. Res. 1997, 36, 3439.

Krajnc, M.; Levec, J., A IChE J., 1996, 42 , 1977.

Li, R.; Thornton, T. D.; Savage, P. E. Environ. Sci. Technol. 1992, 26, 2388.

Matatov-Meytal, Y. I.; Sheintuch, M. Ind. Eng. Chem. Res. 1998, 37, 309.

Modell, M. in H. M. Freeman (Editor), Standard Handbook of Hazardous Waste Treatment and Disposal, McGraw-Hill, New York, 1989, sec. 8.11.

Savage, P. E. Chem. R ev. 1999, 99, 603.

Savage, P. E.; Gopalan, S.; Mizan, T. I.; Martino, C. J.; Brock, E. E. A IChE J., 1995, 41, 1723.

Thornton, T. D.; LaDue, D. E. III; Savage, P. E. Environ. Sci. Technol. 1991, 25, 1507.

Thornton, T. D.; Savage, P. E. Ind. Eng. Chem. Res. 1992a, 31, 2451.

Thornton, T. D.; Savage, P. E. A IChE J., 1992b, 38, 321.

Yen, T. F.; Tang, J. I. S.; Washburne, M.; Cohanim, S. 1982 EPA-600/4-82-038.

Yu, J.; Savage, P. E. Ind. Eng. Chem. Res. 1999, 38, 3793.

Zhang, X.; Savage, P. E. Catal. Today. 1998, 40, 333. 